\title{
Teorie charity (Caritaswissenschaft) jako zdroj a inspirace dnešní teologie Peter Fonk
}

\begin{abstract}
Abstrakt
Do jaké míry může být teologie, a konkrétně teologická teorie charity, zdrojem poznání přicházejícím zvenku (locus alienus) pro teorii a praxi sociální práce? Zde nelze opomenout Ježíšovo přikázání lásky k Bohu a bližním jako podstatný znak křest̉anství. Láska k Bohu je věrohodná do té míry, jak ji Ize zakusit a jak je konkretizována v lásce k bližním. Charita a diakonie tedy mohou sloužit jako znak uskutečňování křest’anské existence vủbec a odkazovat na jádro křest’anské ortopraxe: Služba bližním je vždy také službou Bohu. Teologická teorie charity si tudíž zaslouží privilegované místo v rámci teologie, jejíž základní úkol se zde setkává se sebepojetím všech forem sociální práce, v různých dimenzích pomáhání, doprovázení, péče a opatrování.
\end{abstract}

Klíčová slova: charita, diakonie, teologická teorie charity, loci theologici, sociální práce, skutky milosrdenství, láska k Bohu a bližním, služba bližním, poslední soud, transformační procesy společnosti, ortopraxe, solidární jednání, motu proprio „Intima Ecclesiae natura“

\section{Preliminaria}

V teologii má článek učení o tzv. loci theologici - míst, v nichž se vytváří teologické poznání - od doby průkopnického díla Melchiora Cana „De locis theologicis“ z roku 1563 své pevné místo v teologickém učení o poznání a představuje v učení o principech a metodách důležitý pojem. Za loci theologici se označují zdroje směrodatné a náležité pro získání poznání, stanovení úsudku a vedení důkazů, v nichž je normativně hmatatelná a objektivně odvoditelná tradice víry.

Učení loci odpovídá dobovému chápání teologického poznání a svébytnosti různých důkazních míst v jejich specifické relevanci poznání.

Seznam loci theologici podle Cana předkládá následující celkový obraz:

(1) kanonické knihy Písma sv., (2) nezapsaná tradice Krista a apoštolů, (3) obecná církev (Ecclesia catholica), (4) koncily, (5) římská církev, (6) církevní Otcové, (7) teologové, (8) přirozený rozum, (9) filozofové, (10) lidské dějiny. Z toho jsou body 1-7 považovány za teologii vlastní (loci theologici proprii), zatímco body 8-10 za do jisté míry „požívající občanstvi“ (avšak vposledu jsou loci theologici alieni).

V této studii se však otázka utváření úsudku a získávání poznání obrací. Otázka výzkumu již nezní: Z jakých vlastních a cizích zdrojů získává teologie své náhledy a poznatky? Spíše je položena 
takto: Do jaké míry může teologie být jedním z vnějších zdrojů poznání (locus alienus) pro teorii a praxi sociální práce?

Vzhledem $k$ tomu, že autor pracuje na univerzitě v Pasově jako vědec zabývající se teologickou teorií charity a jako teologický etik a v širokém poli sociální práce se pohybuje jen výběrově na bázi jednotlivých seminář a projektů, omezuje se na to, že ze svého pohledu představuje jen vybrané perspektivy svého oboru, které by mohly přispět k zodpovězení daného tématu.

$\mathrm{V}$ textu je tedy dále $\mathrm{v}$ důležitých základních rysech nastíněn vývoj charitní a diakonické práce a její reflexe $\mathrm{v}$ rámci univerzitní teologické teorie charity a na konci je uvedena krátká úvaha k otázce, zda a do jaké míry by mohly být tyto výsledky relevantní pro teorii sociální práce.

\section{Láska k bližnímu jako původ charitativního jednání církve}

Kdo sleduje dějiny organizované charity a diakonie až $\mathrm{k}$ jejich původu, narazí nevyhnutelně na jejich biblické kořeny. V centru Ježíšova etického zvěstování je bezesporu přikázání lásky $\mathrm{k}$ bližnímu - přesněji řečeno: hlavní přikázání lásky k Bohu a bližnímu (Mt 22,37 par; L 10,27n). To patří tak samozřejmě a zásadně k podstatě křest’anství, že je považováno v pravém slova smyslu za náboženství lásky $\mathrm{k}$ bližním. Bylo by jistě přehnané z toho vyvozovat, že praxe lásky k bližním je vyhrazena pouze křest’anství. Avšak přece jen si v něm nárokuje výsostné postavení, protože se bezprostředně přiblížila $\mathrm{k}$ ústřednímu přikázání lásky $\mathrm{k}$ Bohu a je s ním neoddělitelně spojována. Z toho důvodu se přikázání lásky k bližním přímo nabízí jako teologický základ charitativní diakonie. Proto nikdo menší než sám Karl Rahner důrazně zastupoval pojetí, že služba bližnímu je zároveň také službou Bohu. ${ }^{1}$ Přijmeme-li jeho pojetí, což má své opodstatnění, pak sice lze mravní akt a akt spásy odlišit pojmově, nikoliv však reálně. ${ }^{2}$ Rahnerova teze, která jde ještě dále, „(...) že totiž všude tam, kde pravá láska k člověku dosáhne své vlastní podstaty a své mravní absolutnosti a hloubky, jakkoliv je ve skutečném řádu spásy podložena a překonána Boží spásnou milostí, je také caritas vůči Bohu, at již je jako tato caritas subjektem tematizována či nikoliv“"3, může pro někoho snad zacházet až příliš daleko. $\mathrm{V}$ tomto formálním vyhrocení teze identity by mohla tato teze ještě i dnes zastrašit některé teology. Pokud však tuto dogmaticky přinejmenším diskutabilní tezi dále promýšlíme, lze z ní snadno vyvodit, že věrohodnost církevního poselství stojí a padá také s věrohodností charity nebo diakonie, protože skrze ni je dosvědčována a zakoušena Boží láska k lidem.

Tento závěr je podložen biblickým textem. Přinejmenším se vykazuje jako bezprostředně umožňující návaznost. To potvrzuje svědectví textu, který jasně vyzdvihuje spojitost lásky k Bohu a lásky k bližnímu v centru Ježíšova etického hlásání - ne ve formě normatické pareneze, ale v modelově etické, narativní řeči: Láska $\mathrm{k}$ Bohu je věrohodná do té míry, jak je možno ji zakusit a jak je konkretizována v lásce $\mathrm{k}$ bližnímu.

Za jeden $z$ vrcholných textů, který toto jádro křestanské ortopraxe př́mo exemplárně ozřejmuje, je právem považována Ježíšova řeč o posledním soudu nacházející se v Matoušově evangeliu. Pohled do biblického textu je smysluplný, protože tak ještě zřetelněji vystoupí do popředí ono nové, co vyšlo z křestanství a co na motivační úrovni rozvinulo trvalou účinnost.

Srov. Karl RAHNER, Über die Einheit von Nächsten- und Gottesliebe, in: Schriften zur Theologie, VI., Einsiedeln - Zürich - Köln: Herder Verlag, 1968, s. 277-298.

2 Srov. Tamtéž, s. 286.

3 Srov. Tamtéž, s. 286. 


\section{O posledním soudu (Mt 25,31-42)}

31 Až přijde Syn člověka ve své slávě a všichni andělé s ním, posadí se na trůnu své slávy; 32 a budou před něho shromážděny všechny národy. I oddělí jedny od druhých, jako pastýř odděluje ovce od kozlů, 33 ovce postaví po pravici a kozly po levici. 34 Tehdy řekne král těm po pravici: ,Pojd’te, požehnaní mého Otce, ujměte se království, které je vám připraveno od založení světa. 35 Nebot' jsem hladověl, a dali jste mi jíst, žíznil jsem, a dali jste mi pít, byl jsem na cestách, a ujali jste se mne, 36 byl jsem nahý, a oblékli jste mě, byl jsem nemocen, a navštívili jste mě, byl jsem ve vězení, a přišli jste za mnou.' 37 Tu mu ti spravedliví odpovědí: ,Pane, kdy jsme tě viděli hladového, a nasytili jsme tě, nebo žíznivého, a dali jsme ti pít? $38 \mathrm{Kdy}$ jsme tě viděli jako pocestného, a ujali jsme se tě, nebo nahého, a oblékli jsme tě? 39 Kdy jsme tě viděli nemocného nebo ve vězení, a přišli jsme za tebou?' 40 Král odpoví a řekne jim: ,Amen, pravím vám, cokoliv jste učinili jednomu z těchto mých nepatrných bratří, mně jste učinili.' 41 Potom řekne těm na levici: ,Jděte ode mne, prokletí, do věčného ohně, připraveného dáblu a jeho andělům! 42 Hladověl jsem, a nedali jste mi jíst, žíznil jsem, a nedali jste mi pít, 43 byl jsem na cestách, a neujali jste se mne, byl jsem nahý, a neoblékli jste mě, byl jsem nemocen a ve vězení, a nenavštívili jste mě.‘ 44 Tehdy odpovědí i oni: ,Pane, kdy jsme tě viděli hladového, žíznivého, pocestného, nahého, nemocného nebo ve vězení, a neposloužili jsme ti?‘ 45 On jim odpoví: ,Amen, pravím vám, cokoliv jste neučinili jednomu z těchto nepatrných, ani mně jste neučinili.' 46 A půjdou do věčných muk, ale spravedliví do věčného života." (Dan 12,2)

V tradici křestanské spirituality byly z řeči o posledním soudu velmi záhy odvozeny skutky tělesného milosrdenství: sytit hladové, napájet žíznivé, odívat nahé, ubytovávat cizince, navštěvovat nemocné, osvobozovat vězně, pohřbívat mrtvé. ${ }^{5}$

Pojmy „charitativní praxe“ či „diakonie“6 se v této studii nadále používají synonymně, protože označují stejnou věc: rozhodné „být zde pro druhé“. To patřilo v době raných křestanských obcí, tedy v 1. a 2. století k identitě církve právě tak jako kázání evangelia. Je to jedna z cest, jak hlásat Ježíšovo poselství. Jestliže křestané jako obec působili pomocí a uzdravováním tam, kde byli lidé v nouzi, pak to bylo považováno - podle slov 1. listu apoštola Petra - za kázání beze slov (1 Pt 3,1n).

Jestliže si dnes klademe otázku, co tehdy nekřestany tak uvádělo v úžas, pak dejme nejlépe slovo dobovým svědkům. Tertulián, teolog, který žil v letech 160-220 po Kristu, podává zprávu, že křestané vydávali své peníze za obživu a pohřbívání chudých členů obce a za osoby, které neměly příbuzné, za vdovy a sirotky, za lidi, kteří se nezaviněně dostali do nouze, za péči o nemocné a za křestany, kteří byli kvůli své víře posíláni na nucené práce a do vyhnanství.

Tato nezištná charitativní činnost byla tím největším trumfem, který mohla raná církev vynést před pohanským světem a kterým ve značné míre získávala na věrohodnosti. Svým jednáním v krizích a při katastrofách se křestané nápadně lišili od svého okolí.

V pozdní antice sice již bylo známé osobní mecenášství a individuální dobročinnost, a tudíž i for-

Český překlad byl převzat z: Bible, Písmo svaté Starého a Nového zákona, ekumenický překlad, Praha 1979.

5 Poslední uvedený skutek - pohřbívat mrtvé - se sice ještě v Matoušově evangeliu nevyskytuje, byl však připojen k uvedeným šesti skutkům milosrdenství, aby se dosáhlo posvátného čísla sedm. To bylo oprávněné i proto, že pietní zacházení se zemřelými bylo důsledkem víry ve vzkř́išení, a tudíž k němu zavazovalo všechny členy křestanských obcí praxí žité víry.

6 Pojmy charita a diakonie se dnes používají většinou jako zkrácené označení pro náboženské dobročinné organizace - v Německu Diakonické dílo a Německý svaz charity, v ČR Diakonie ČCE a Česká katolická charita, takže „charita“ se používá také jako synonymum pro sociální práci katolické církve, diakonie jako synonymum pro sociální práci evangelické církve. 
my dobrovolné sociální angažovanosti, které mohou být považovány za analogii Corporate Social Responsibility (CSR) vzniklé v angloamerickém světě. Avšak okolnost, že sociální angažovanost se stala přikázáním lásky k bližním závaznou pro všechny členy celého společenství věřících a že diakonie sloužila jako kód pro uskutečňování křest’anské existence, byla pro tehdejší svět nová a vyvolala všeobecnou pozornost. ${ }^{7}$

Diakonie dodnes platí - vedle hlásání (martyria, kerygma) a liturgie (leiturgia, bohoslužba) - ke třem hlavním projevưm církve, $\mathrm{v}$ nichž manifestuje podstatný prvek své identity.

Perikopa o posledním soudu je posledním textem kázání o opětovném příchodu Páně (parusie), jehož utrpení bezprostředně nastává. Po svém zmrtvýchvstání (Velikonoce) a návratu k Otci (nanebevstoupení Páně) přijde povýšený Kristus opět na konci časů a bude soudit lidi. Zatímco jedni získají věčnou spásu, druzí propadnou věčnému trestu. Důvod, proč rozlišování mezi dobrými a zlými probíhá tak cíleně a s tak neochvějnou jistotou, osvětluje Ježíš podobenstvím, které bylo jeho posluchačům důvěrně známé z jejich každodenního života:

V Palestině se držely ovce a kozy společně v jednom stádu. Přitom ovce byly bílé a kozy černé. Když mladí kozli dosáhli stáŕí, ve kterém byli obvykle poráženi a snědeni, docházelo k vyřazování. Otázku, jak mohl pastevec rozlišit černé kozy od bílých ovcí, by nikdo nepoložil. Stejně tak by nikdo nezpochybňoval jistotu rozlišení. Hodnocení levé strany jako strany zkázy (zlé) a pravé strany jako spásné (dobré) se používá i dnes a je doloženo již v biblické a mimobiblické literatuře. ${ }^{8}$ Pastýře je $\mathrm{v}$ této perikopě třeba chápat jako metaforu pro Krista, stádo ovcí a koz jako metaforu pro křestanskou obec, která vytváří societas mixta, ve které žijí společně promíšeni jak dobří, tak zlí. Obraz porážky ještě jednou zesiluje myšlenku soudu a odsouzení. V této souvislosti je velmi důležité, že se zde jedná o rozhodnutí o životě a smrti, požehnání a prokletí, které v zásadě nečiní Kristus paruzie. Rozhodnutí je na lidech samotných - i když si toho nejsou vůbec vědomi: Všechno, co učinili pro své bližní v lidské náklonnosti, či o vưči nim zanedbali, je forma, jak se v bližním setkat s Bohem. Jinak řečeno: Charita nebo diakonie je forma služby Bohu.

Motiv nevědomosti jak u spravedlivých, tak i nespravedlivých poskytuje evangelistovi Matoušovi př́ležitost, jak ještě jednou zopakovat, na čem mu záleží: Nerozhoduje dogmatika nebo explicitní vyznávání učení, ale praxe křest’ansky chápané lásky k bližním. Rozhodující nakonec není vyznávání pravého učení, ale svědectví skrze jednání, které se líbí Bohu. Jinak řečeno: Primát nespočívá ve vyznávání pravého učení, ortodoxii, ale ve svědectví ortopraxe, správného jednání.

$S$ čím se toto svědectví bezpochyby může identifikovat, se explicitně uvádí v kázání o posledním soudu. Kdo koná skutky milosrdenství, ten naplňuje Boží vůli a může dosáhnout spásy. Takže se může zcela dobře stát, že - řečeno z dnešního hlediska - ne ti, kteří jsou privilegovaní ve společenství věřících, jejichž formální členství ve společenství církve je mimo pochybnost, patří k těm, které Soudce vyvolil, nýbrž ti marginalizovaní, kteří možná vypadli z právní příslušnosti a svazků solidarity a jsou proto často přehlíženi nebo vytlačeni na okraj. V tomto kontextu pak nepřekvapí, že ti, kteří nakonec budou patřit k vyvoleným, z toho budou velmi užaslí.

To jsou lidé, kteří nevyznávají víru ústy, kteří se možná vưbec necítí být křestany - možná i proto, že evangelium nikdy nepoznali, nebo alespoň ne v jeho existenciálně přesvědčivé formě -, kteří však podle evangelia žijí a jednají.

I oni mají vyznání víry, mají své krédo: ovšem nikoliv krédo slov, ale krédo skutků. Jinak řečeno: ne krédo hlavy a rtů, nýbrž krédo srdce a pomáhajících rukou.

7 Srov. Arnold ANGENENDT, Die Geburt der christlichen Caritas, in: Caritas. Nächstenliebe von den frühen Christen bis zur Gegenwart, ed. Christoph STIEGEMANN, Petersberg: Michael Imhof Verlag, 2015, s. 40-51.

8 Srov. Lothar KULD, 34. neděle během roku, cyklus A - neděle Krista Krále: Mt 25,31-46. 
II. vatikánský koncil v „Dogmatické konstituci o církvi“ (LG 16) uvádí, že tito lidé mohou rovněž dosáhnout spásy. ${ }^{9}$

Karl Rahner tématizoval s odkazem na tento text II. vatikánského koncilu situaci těchto lidí v dèjinách spásy a v souvislosti s nimi hovořil o „anonymních křestanech“ ${ }^{“ 10}$ - vytvořil tak pojem, který je od té doby často citován, ovšem také kritizován.

U tohoto pojmosloví se nejedná o poslední zoufalý pokus, vzhledem ke klesajícímu počtu návštěvníků kostelů a $\mathrm{k}$ trvajícím výstupům $\mathrm{z}$ církve, okrášlit obtížnou situaci nejen katolické církve, ale většiny křestanských církví a o snahu zahrnout do nich i ty, kteří by se tomu vší silou bránili. Spíše jde o vyjasnění, že př́islušnost ke společenství spásy nekončí formální příslušností k církvi a že Boží spásná vůle sahá dále, než jsou hranice konfesí či náboženství. Křestané zde nemají, stejně tak jako všichni ostatní, žádná privilegia. Až se budou při posledním soudu rozdělovat místa a lidé budou rozdělováni na spasené a zavržené, bude soudce světa rozlišovat podle kritérií láskyplného jednání vůči bližním či jeho odpíráním tak, jak se to projevuje ve skutcích milosrdenství. Řečeno jednou větou: diakonická či charitativní praxe není dobrovolný závazek křestanů, ale forma setkávání se v trpících bližních se samotným Kristem. To je cesta ke spáse.

\section{Institucionální uspořádání charity v kontextu společenských transformačních procesů}

Nyní už se od charitativně diakonické praxe rané církve až po institucionální a profesionalizované formy dobročinných organizací urazila dlouhá cesta. Co bylo v Ježíšových dobách možno demonstrovat ještě na př́kladu individuálních etických postojů, nelze bezprostředně aplikovat na aktuální situaci naší současnosti.

Na tento stav nedávno poukázali také Arnd Küppers a Peter Schallenberg, či přesněji, připomněli dřivější kritické poznámky Adama Smithe tím, že poukazují na dějinné pozadí Ježíšova etického poselství, které prostě nesmí být utlumováno:

A zde spočivá již první problém, na který upozorňoval již skotský osvícenský filozof Adam Smith. Ve své Teorii mravních citů z r. 1759 ukázal, že etika založená na soucitu funguje jen v malých sociálních skupinách. Avšak v moderním nepřehledném světě naše etické city často selhávají. ${ }^{11}$

Odkaz na Adama Smithe jistě není neoprávněný. Naznačení problému, který formuloval z hlediska osvíceného myslitele 18. století, se ve 20. století ujal Arnold Gehlen a dále jej rozvinul. Ve svém pozdějším díle „Morálka a hypermorálka“ formuluje tezi, že existuje více funkcionálně a geneticky nezávislých kořenů morálky, takže politicky a společensky velmi aktuální otázky etiky mohou být $\mathrm{v}$ důsledku toho pojednávány minimálně na dvou rovinách: jednak na rovině humanitarismu, do jehož rámce je tř̌eba zasadit morálku malých skupin a etiku lásky $\mathrm{k}$ bližním, a jednak na rovině etiky institucí, které strukturálně sledují jiné zákony než morálku face-to-face. Žádná z obou

9 „Věčné spásy mohou totiž dosáhnout všichni, kdo bez vlastní viny neznají Kristovo evangelium a jeho církev, avšak s upř́ímným srdcem hledají Boha a snaží se pod vlivem milosti skutečně plnit jeho vůli, jak ji poznávají z hlasu svědomí. Božská prozřetelnost neodpírá pomoc nutnou ke spáse těm, kteří bez vlastní viny ještě nedošli k výslovnému uznání Boha, ale snaží se, ne bez Boží milosti, o dobrý život.“ (LG 16)

10 Karl RAHNER, Die anonymen Christen, In: Schriften zur Theologie, VI., Einsiedeln - Zürich - Köln: Herder Verlag, 1968, s. 545-554.

11 Arndt KÜPPERS - Peter SCHALLENBERG, Flucht und Migration als Herausforderung christlicher Nächstenliebe, Theologie der Gegenwart 3/2016, s. 195. 
rovin nemůže být převedena do té druhé nebo na ni být redukována; zvláště pokus převést etiku lásky k bližním založenou na personálních kategoriích na rovinu institucionální etiky by etiku lásky k bližním zcela přetížilo, a tím by ji v posledku odsoudilo ke ztroskotání.

I když Gehlen ve své knize „Morálka a hypermorálka“ $v$ žádném př́ípadě nezastával jen konformní, ale i veskrze sporné pozice, potvrzuje se základní teze jeho pozdního díla v téměř 2000leté historii charity od jejích biblických pramenư ${ }^{12}$ až po současnost. I tam se stále vyskytovaly transformační procesy: charita, př́padně diakonie, započala již v rané církvi, pokračovala přes zakládání prvních xenodochií, přešla do rukou katedrálních kapitul a klášterů, vedla ve vrcholném stř̌edověku k zakládání takzvaných občanských špitálů, $\mathrm{v}$ raném novověku byla částečně vytlačena výskytem veřejné, obzvlášt komunální dobročinnosti, zažila po sekularizaci renezanci, která vedla v důsledku sociálního katolicismu v 19. století k zakládání prvních svazů charity.

Jednou větou: Dějiny charity se ubíraly po rozličných cestách a byly velmi proměnlivé. I dnes je vystavena značným společenským transformačním procesům:

Toto jsou některé důležité pojmy: globalizace, migrace, sekularizace, pluralizace a racionalizace. Tyto procesy vyžadují dodnes institucionální zaměření konfesních dobročinných organizací na různých rovinách: konfesní zaměření dobročinné péče je celkově zpochybňováno, mezináboženské a interkulturní zaměření $v$ důsledku procesů pluralizace je nutnější více než kdy dříve, hospodářský vývoj nutí $k$ procesům racionalizace atd. ${ }^{13}$

Výzvy, které z těchto aktuálních společenských transformačních procesů vyplývají, přinutily spolkovou charitu svou službu lidem institucionalizovat a profesionalizovat.

Právem tedy Heinrich Pompey konstatuje:

Nestrukturovaná, nevýběrová pomoc se míjí účinkem. Čistě spontánní charita nespojuje síly a nevyvijí priority jednání. Přes charitativní závazky jednotlivců i celé církve musí být vytvořeny odpovídající organizace. Organizátory je přitom nutno uschopnit pro kvalitní management, $\mathrm{k}$ výkonnému ekonomickému spravování prostředků, k právnicky kompetentnímu rízení sociální a pečovatelské práce atd. ${ }^{14}$

Z profesionality a křestanské autentičnosti by se však neměly činit protiklady, jak již před mnoha lety - se zřetelem na vztah ekonomie a etiky - velmi trefně vyjádřil Benedikt XVI. alias Josef Ratzinger:

Morálka, která se domnívá, že může pomíjet věcnou znalost ekonomických zákonitostí, není morálkou, ale moralismem, tedy opakem morálky. Věcnost, která se domnívá, že se může obejít bez étosu, je zneuznáním reality člověka a tudíž nevěcná. ${ }^{15}$

12 Tím nemá být vyloučeno, že křestanská charita má své předchůdce již ve starém Egyptě. Viz ANGENENDT, Die Geburt der christlichen Caritas, s. 40-51.

13 Rauf CEYLAN - Michael KIEFER, Ökonomisierung und Säkularisierung. Neue Herausforderungen der Konfessionellen Wohlfahrtspflege in Deutschland, Wiesbaden: Springer Verlag, 2017, s. 1.

14 Heinrich POMPEY, Zur Neuprofilierung der caritativen Diakonie der Kirche: Die Caritas-Enzyklika „Deus Caritas Est“: Kommentar und Auswertung, Würzburg: Echter Verlag, 2007, s. 96.

15 Joseph Kardinal RATZINGER, Marktwirtschaft und Ethik, in: Stimmen der Kirche zur Wirtschaft, ed. Lothar ROOS, Köln: J.P. Bachem Verlag, 1986, s. 58. 


\section{Teologická teorie charity v centru univerzitní teologie}

Dodnes je charita nebo diakonie - vedle hlásání a liturgie - považována za jednu z hlavních činností církve, v nichž se manifestuje její identita. Tato trojí služba církve byla sice stanovena II. vatikánským koncilem, a ještě důrazněji vyzdvižena Würzburgským synodem, avšak po dlouhou dobu chyběla systematicko-teologická reflexe učitelského úřadu ohledně charitativního poslání křestanů a církve vztažená $\mathrm{k}$ praxi a nutnosti spásy charitativní diakonie. To se ovšem změnilo vydáním první encykliky Benedikta XVI. „Deus caritas est ${ }^{“ 16} \mathrm{v}$ prosinci 2005 , kterou je třeba považovat za historicky první dokument úřadu církve. Trvalo pak ještě dalších sedm let, než v motu proprio „Intima Ecclesiae natura"17 byla do sborníku kanonického práva přijata charitativní zodpovědnost biskupa, a tím bylo pokryto i normativní prázdné místo. Nebot řeč o Bohu bez praxe charity není křestanskou řečí o Bohu.

Avšak dodnes není v teologickém vzdělávání žádná etablovaná teologická disciplína, která by tuto oblast pokryla. Výjimku tvoří německy hovořící země, kde je alespoň na některých teologických fakultách nebo institutech zastoupena teologická teorie charity nebo teologie charity jako samostatný obor.

Ohledně důvodů, proč je teologická teorie charity na rozdíl od katolického sociálního učení nebo křestanské sociální etiky v univerzitní teologii relativně málo zastoupena, je možno zastávat různé názory. Př́kazem doby je tedy nezbytnost zavést teologickou disciplínu teologické teorie charity do základního seznamu oborů teologického vzdělávání jako samostatný studijní obor, který má budoucnost a odpovídá praxi.

V tomto směru je právě motu proprio „Intima Ecclesiae natura“ prvním kanonickým a tím právně závazným dokumentem. Biskupưm se zde dává na vědomí, že diakonie nebo charita je ústředním aspektem celého jejich rozsahu zodpovědnosti. Papež František sám je zde dobrým příkladem. Motu proprio je ale také velkým př́nosem nové evangelizace a posílení ve víre, nebot mnozí, kteří pracují v katolických organizacích nebo v křestanských nevládních organizacích, nově objevují, že jejich jednání $\mathrm{v}$ žádném př́padě nepředstavuje marginální aspekt církevního jednání, ale naopak že je zakotveno v centru žitého svědectví víry.

Tím se také stanoví teologické místo autentické teologické teorie charity v kánonu teologických disciplín: v ní obsažená jedinečná syntéza teorie a praxe je dostatečným důvodem, aby jí bylo přiznáno privilegované místo $\mathrm{v}$ rámci teologie. Je reflexí soteriologie uváděné do praxe, a slouží tak jako teoretická vůdčí věda pro konkrétní službu lásky k bližním. Křestanská myšlenka solidarity by pak mohla - nikoli jako alternativa $\mathrm{k}$ myšlence sociálního státu, nýbrž $\mathrm{v}$ jeho rámci - nově získat na významu, takže solidaritu a milosrdenství bychom mohli označit za inovativní zdroj sociální spravedlnosti.

Protože myšlenka moderního sociálního státu očividně naráží na své hranice, obrací se charita a diakonie také $k$ těm, kteří propadají rídkou sítí zákona. Teologická teorie charity jako univerzitní disciplína směřuje svi̊j pohled především na možnosti pomoci, jak by na stř̌ední úrovni a mikroúrovni mohla být prospěšná těm, kteří si sami pomoci nemohou, bud’ proto, že nemají žádné loby nebo jsou vyřazeni ze společenské participace.

Tím se setkává jejich základní úkol se sebepojetím všech forem sociální práce, která působí v různých dimenzích pomáhání, doprovázení, péče a opatrování.

Solidární jednání, ve kterém je možno zakoušet jednotu Boží lásky a lásky k bližním, odmítá

16 Benedikt XVI., Deus caritas est. An die Bischöfe, an die Priester und Diakone, an die gottgeweihten Personen und an alle Christgläubigen über die christliche Liebe, VApS 171, 2005.

17 Benedikt XVI., De intima ecclesiae natura. Motu Proprio über den Dienst der Liebe, VApS 195, 2012. 
jakýkoliv etický partikularismus a na jeho místo dosazuje rozhodný etický universalismus. To má jasné důsledky jak pro křestanskou dobročinnost, tak také pro sociální práci v jejích různých formách: Každý člověk, který je v nouzi, má nárok na pomoc, která není vázána žádnými podmínkami. Tuto pomoc je třeba poskytnout bez výhrad, to znamená bez ohledu na náboženské přesvědčení, národní a etnickou př́slušnost, pohlaví, barvu pleti nebo sexuální orientaci. Pomoc př́sluší i tomu, kdo spáchal nějaký zločin nebo se prohř̌šil proti Bohu. Slovo a příklad Ježíše, který se obracel s láskou i ke slabým, chudým, vyloučeným a k hř́šníkủm, o tom nepřipouští žádnou pochybnost.

Překlad: Mgr. Marta Rynešová

\section{Kontakt}

Msgr. Prof. Dr. Dr. Peter Fonk

Universität Passau

Lehrstuhl für Theologische Ethik

Michaeligasse 13, Passau

Peter.Fonk@uni-passau.de 